\title{
Assessment of Groundwater Quality of Selected Inland Valley Agro-ecosystems for Irrigation in Southwest Nigeria
}

\author{
Olatunji S. Aboyeji ${ }^{1}$ and Olayinka O. Ogunkoya ${ }^{2}$ \\ ${ }^{I}$ Regional Centre for Training in Aerospace Surveys (RECTAS), Ile-Ife, Osun State, Nigeria. \\ ${ }^{2}$ Department of Geography, Obafemi Awolowo University, Ile-Ife, Osun State, Nigeria. \\ Corresponding author: \\ O. S. Aboyeji, Regional Centre for Training in Aerospace Surveys (RECTAS), Ile-Ife, Osun State, Nigeria \\ E-mail: olatunjiaboyeji@yahoo.com
}

(received in March 2015; accepted in June 2015)

\begin{abstract}
The study assessed the quality of groundwater of 6 inland valley (IV) agro-ecosystems with a view to establishing their characteristics for cropping in the derived savannah of southwest Nigeria. Water samples were collected in piezometers during the rainy and dry seasons and analysed for physicochemical and heavy metal properties. Major water quality indices and comparison with stipulated standards were used to determine the usability of the waters for irrigation. The study showed that the waters were generally neutral to slightly alkaline, with the dominance structure of the major cations and anions in the order of $\mathrm{Na}^{+}>\mathrm{Ca}^{2+}>\mathrm{K}^{+}>\mathrm{Mg}^{2+}$ and $\mathrm{Cl}^{-}>\mathrm{SO}_{4}{ }^{2-}>\mathrm{HCO}_{3}^{-}>\mathrm{CO}_{3}$. The concentration of heavy metals was generally within the recommended limits for most crops grown in the study area. Major water quality indices (sodium adsorption ratio, soluble sodium percentage, total dissolved solids, permeability index, magnesium adsorption ratio, Kelly's ratio and residual sodium bicarbonate) are generally within the levels acceptable for crop irrigation. Kruskal-Wallis $\mathrm{H}$ test (2-tailed) showed that there was no statistically significant difference in the water quality parameters/indices between the inland valley sites, $P=0.935$. The groundwater of inland valley agro-ecosystems of the study area is generally suitable for agricultural utilisation.
\end{abstract}

Keywords: southwest Nigeria, groundwater, wetland, agriculture, water quality indices.

\section{Introduction}

Agriculture is an important sector of subSaharan Africa's economy, and this is particularly so for Nigeria. Cropping is practised traditionally on upland ecosystems through rain-fed cultivation. However, inadequate agricultural productivity caused partly by increasingly unreliable rainfall, land degradation due to over-cultivation of fragile uplands/marginal lands, and loss of arable lands to non-agricultural uses is a major challenge (Ogunremi et al., 2000; Windmeijer and Andriesse, 1993). The need to cultivate fragile uplands and marginal ecosystems is being heightened due to population pressure and the intensifying demand for food.

An approach towards enhancing agricultural productivity is the sustainable use of ubiquitous wetland ecosystems called inland valleys (IVs) in anglophone countries and bas-fonds/petits bassins versants in francophone countries of West Africa
(Windmeijer and Andriesse, 1993). Inland valleys are relatively shallow and characterised by hydromorphic soils. The United Nations' Food and Agricultural Organization defines them as the upper sections of rivers comprising of valley bottoms or minor colluvial plains and a continuum from their hydromorphic fringes to the uplands. These ecosystems are locally called fadama, akuro and odomiri in the northern, western and eastern parts of Nigeria, respectively (Aboyeji and Ogunkoya, 2014). The wetness of inland valleys is a result of occurrence of some factors, including the presence of an impermeable soil horizon, which retards percolation, overflow of floodwaters into bottom lands/valley fringes, convergence of sub-surface flow lines, and poor surface drainage outlets (Ogban and Babalola, 2003). This makes the ecosystem ideal for both wet and dry season cropping, where 
environmentally sustainable all-season farming could be practised. In spite of the abundance of these ecosystems in southwest Nigeria, however, their potential for crop production has not been fully exploited due to their heterogeneity in terms of morphology, soil types, vegetation, hydrology, and agro-economy (Ogban and Babalola, 2003; Ogunremi et al., 2000; WARDA, 1996). According to Thenkabail and Nolte (1996), only 8 to $20 \%$ of inland valley bottoms and 15 to $22 \%$ of inland valley fringes are being exploited for agriculture in West Africa. Inland valleys, due to annual flooding, could be rich in soil fertility, have potential for rice cultivation during the main cropping season, and be moist enough to sustain upland crops during the dry season (Ogunremi et al., 2000).

A major challenge to utilisation of the valleys for cropping is the dearth of information on the detailed specific characteristics of these valleys that could enable their identification for specific agricultural utilisation (Fagbami and Ajayi, 1990; Ogban and Babalola, 2009). One of the characteristics that need to be understood is the quality of their groundwater with regards to applicability for supplementary irrigation during the dry season. The groundwater, the quality of which depends on the source of recharge and the geological environment through which it flows, has to meet standards for safe use (Mukherjee et al., 2005).

There have been a number of studies on the quality of surface and groundwater for domestic and irrigation purposes in the study area (Adebisi, 1981; Ige et al., 2008; Jaji et al., 2007; Ogunfowokan et al., 2009; Ogunkoya and Adejuwon, 1990; Talabi and Tijani, 2013). Little is, however, known about the quality of groundwater of inland valley eco-systems of the study area, particularly in relation to agricultural utilisation. This study evaluates the quality of groundwater of 3 typologies of inland valleys and assesses the suitability of the waters for irrigation.

\section{Materials and methods}

\subsection{Description of the study area}

The 6 inland valleys investigated belong to 3 typologies commonly found in the study area amphitheatre-like valley-heads (sites Am1 and Am2), valley-side inland valleys (sites VS1 and VS2), and low depression inland valleys (sites LD1 and LD2). These sites are located west of the main trunk of the River Niger in portions of Osun and Kwara states of Nigeria. The entire area falls within latitudes $7^{\circ} 57^{\prime}$ to $8^{\circ} 14^{\prime}$ north and longitudes $4^{\circ} 41^{\prime}$ to $4^{\circ} 58^{\prime}$ east, around the southern foothills of the topographic zone referred to as the Yoruba Hills (see Figure 1). The terrain is underlain by Basement Complex rocks, comprising granites, granite-gneisses, and schist, and consists of plains studded with granite and granitegneiss inselbergs, and hill ranges. The highland features constitute the watersheds, while rivers tributary to the River Niger flow northwards or westwards on the plains. The soils are the ferruginous tropical type that derived from Basement Complex rocks. The character of the soils is a function of the underlying parent materials, the marked rainfall seasonality of the climate, and the woodland vegetation type.

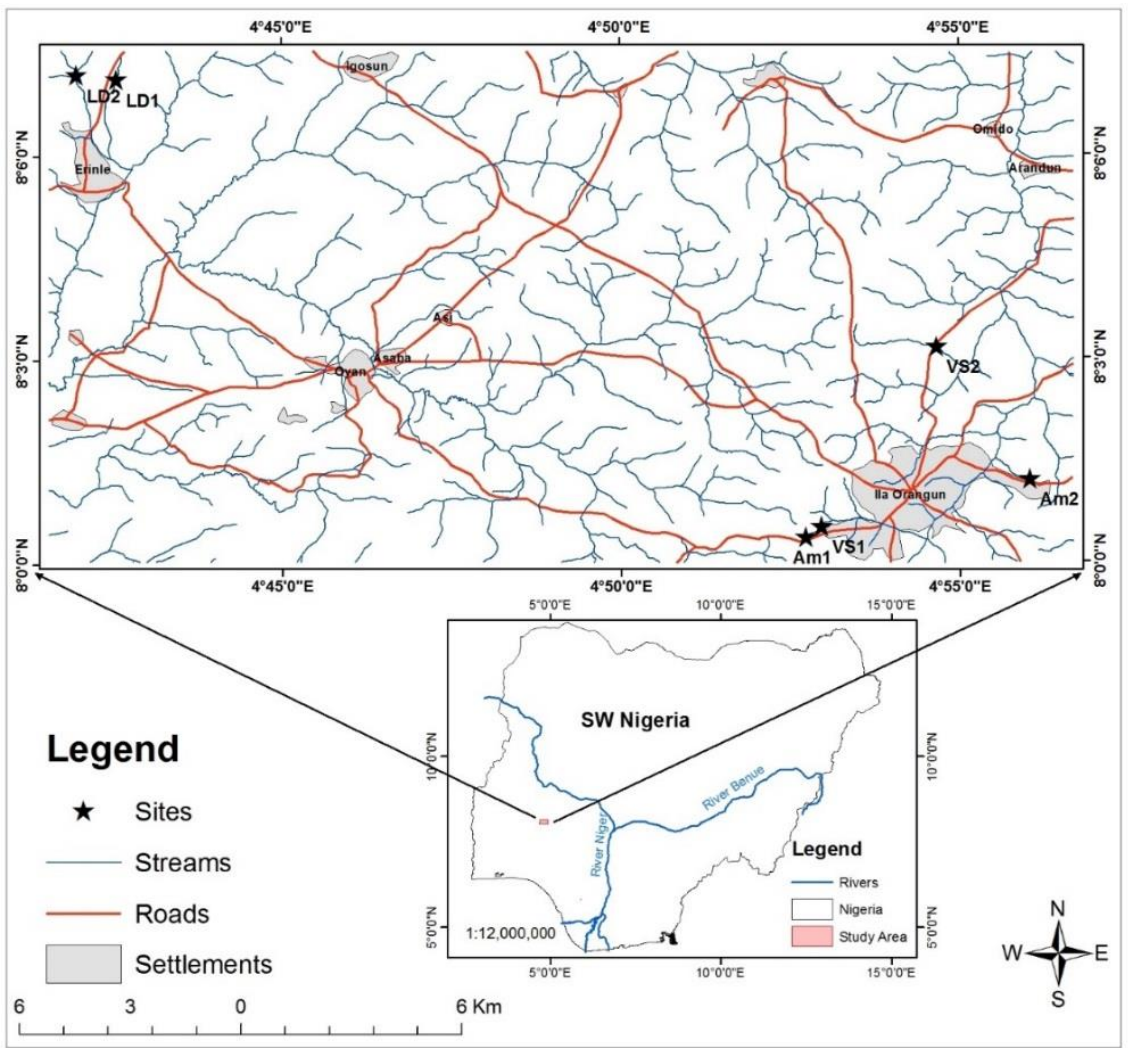

Figure 1. The study area with the sampling sites indicated by the star symbol. 
The climate of the study area is the Koppen's $\mathrm{A}_{\mathrm{w} 1}$ Tropical Wet and Dry type characterised by the dry season extending from November to February/March and the wet season extending from March/April to October (Aboyeji and Ogunkoya, 2014). The temperature is generally high throughout the year with an annual mean of about $26^{\circ} \mathrm{C}$. The mean minimum and maximum temperatures are $20^{\circ} \mathrm{C}$ and $33^{\circ} \mathrm{C}$, respectively. The mean annual rainfall is about $1300 \mathrm{~mm}$, with a bimodal distribution characterised by a rainfall minimum between July and August.

\subsection{Water sample collection and analysis}

Sampling was carried out during the rainy and dry seasons of 2012. Five sets of groundwater samples were collected from piezometers installed at pre-selected locations. The samples were collected mid-May 2011, mid-August 2011, mid-November 2011, mid-January 2012, and mid-March 2012. These months were selected to cover the period when rain begins to be well established (May) through to the peak dry season of March. The number of the samples collected at each site varied according to the valley size and availability of water in the piezometers, as some dried up during the dry season (Figures 2 and 3).
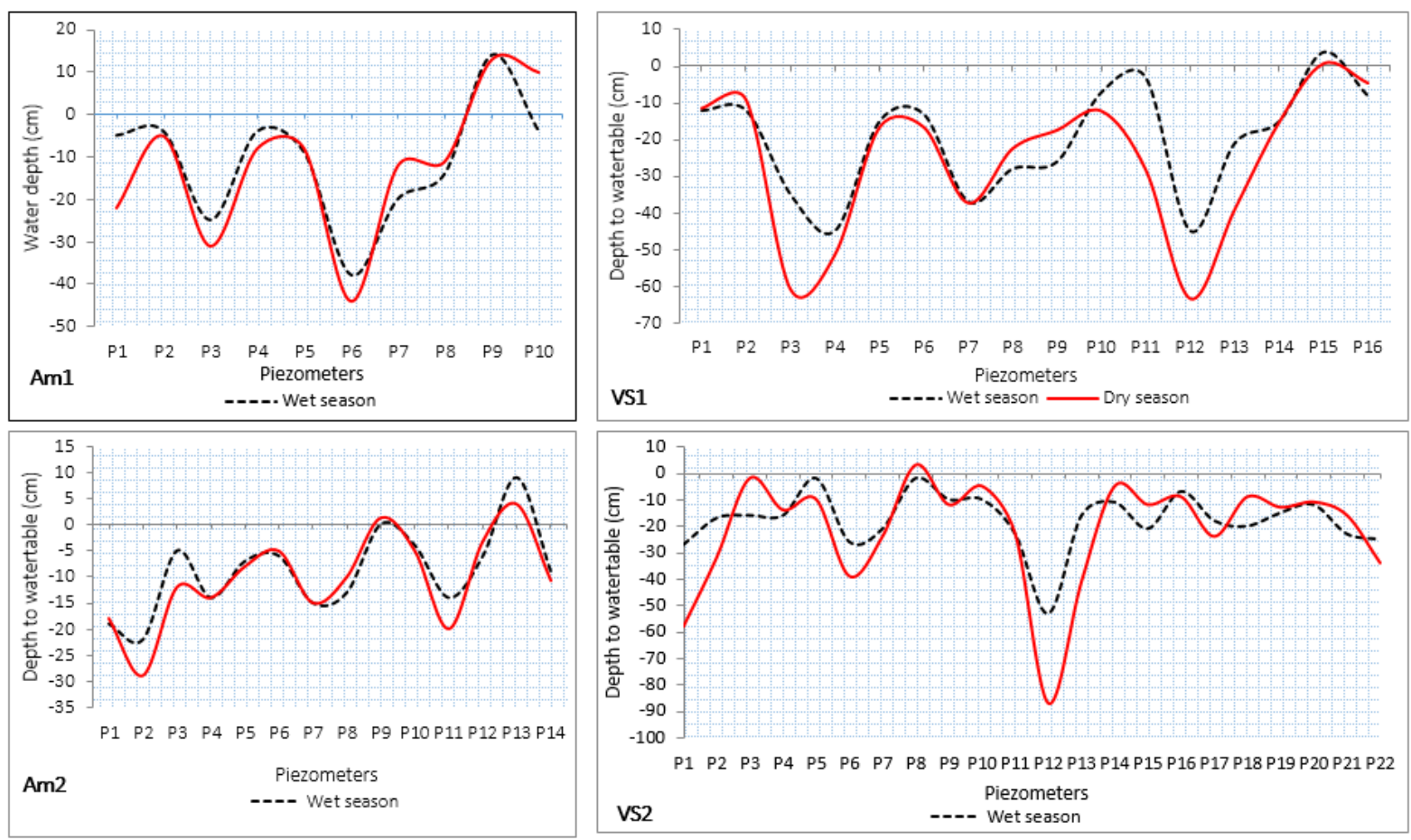

Figure 2. Seasonal pattern of groundwater level fluctuation in Amphitheatre-like (Am) and Valley-side (VS) inland valleys.
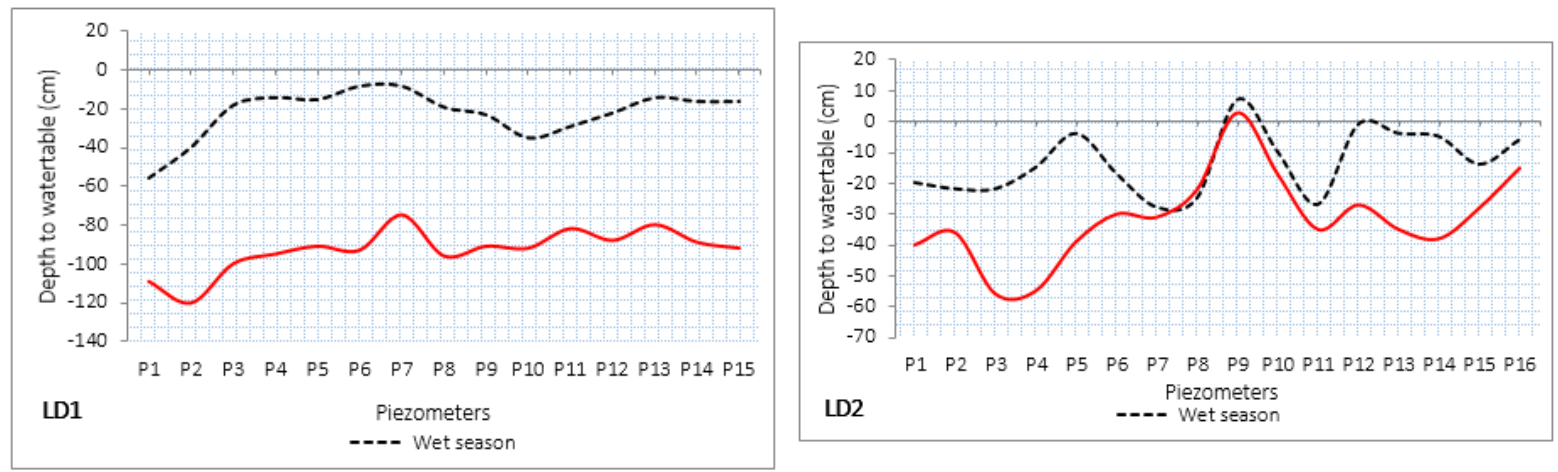

Figure 3. Seasonal pattern of groundwater level fluctuation in low depression $(L D)$ inland valleys.

A total of 25, 24, 19, 20, and 26 water samples were collected in May 2011, August 2011, November 2011, January 2012, and March 2012, respectively. The samples were collected in pre-rinsed plastic bottles using a suction sampler. Prior to sampling at each location, the Buckner flask attached to the sampler and the sample bottle used to store the water were rinsed with the water collected at the location.
The bottles were kept in a chilled box while being transported to the laboratory for analysis. The $\mathrm{pH}$ and electrical conductivity (EC) were measured in situ. Chemical analyses of the water samples were carried out at the laboratory of the Department of Soil Science, Obafemi Awolowo University, Ile-Ife, Nigeria. Each sample was analysed for calcium $\left(\mathrm{Ca}^{2+}\right)$, magnesium $\left(\mathrm{Mg}^{2+}\right)$, potassium $\left(\mathrm{K}^{+}\right)$, and 
sodium $\left(\mathrm{Na}^{+}\right)$, using a flame photometer, while the anions $\left(\mathrm{CO}_{3}^{2-}, \mathrm{HCO}_{3}^{-}, \mathrm{Cl}^{-}\right.$, and $\left.\mathrm{SO}_{4}{ }^{2-}\right)$ were analysed using titration, as described in Page et al. (1982). The heavy metals (iron, copper, zinc, lead and nickel) were analysed using atomic absorption spectrometry (AAS).

The results were used to assess the water quality of the sites for agricultural utilisation using the following water quality indices (all the ions are expressed in milligram equivalents per litre, meq/L):

- Sodium Adsorption ratio (SAR) was calculated using the following equation (Raghunath, 1987; Wallender and Tanji, 2012):

$$
S A R=\frac{N a^{+}}{\sqrt{\left(\frac{C a^{2+}+M g^{2+}}{2}\right)}}
$$

- Soluble sodium percentage $(\% \mathrm{Na})$ was calculated using the equation below (Todd and Mays, 2005):

$$
\% N a=\frac{N a^{+}+K^{+}}{N a^{+}+C a^{+}+M g^{+}+K^{+}} \times 100
$$

- Total dissolved solids (TDS) were estimated from specific conductance values by multiplying with a factor of 0.64 (i.e. TDS $(\mathrm{mg} / \mathrm{L})=\mathrm{EC}(\mu \mathrm{S} / \mathrm{cm}) \times 0.64)$, which is taken as the conversion factor for most natural waters (Richards et al., 1954; Wallender and Tanji, 2012).

- Permeability index (PI) was calculated according to Doneen (1964) (Raghunath, 1987) by the following equation:

$$
P I=\frac{\mathrm{Na}^{+}+\sqrt{\mathrm{HCO}_{3}^{-}}}{\mathrm{Ca}^{2+}+\mathrm{Mg}^{2+}+N a^{+}} \times 100
$$

- Magnesium adsorption ratio (MAR) was calculated using the following equation (Prasanth et al., 2014; Raghunath, 1987):

$$
M A R=\frac{M g^{2+}}{C a^{2+}+M g^{2+}} \times 100
$$

- Kelly's ratio (KR) was calculated based on Kelly (1963) and the following equation:

$$
K R=\frac{N a^{+}}{C a^{2+}+M g^{2+}}
$$

- Residual sodium bicarbonate (RSBC) was calculated following Gupta and Gupta (1987):

$$
\mathrm{RSBC}=\mathrm{HCO}_{3}^{-}-\mathrm{Ca}^{2+}
$$

The results of these indices were compared with known or stipulated standards. Non-parametric tests (Mann-Whitney $U$ test and Kruskal-Wallis test) were used to determine if any difference existed between the hydro-geochemistry of the inland valleys.

\section{Results and discussion}

3.1 Physicochemical characteristics. Concentration of heavy metals in groundwater

Table 1 presents the summary statistics of the physicochemical characteristics and concentration of heavy metals of the groundwater samples. The groundwater samples were generally acidic to alkaline with $\mathrm{pH}$ ranging from 5.03 (Am1) to 8.80

\begin{tabular}{|c|c|c|c|c|c|c|c|c|c|c|c|c|c|}
\hline IV & Statistic & $\mathbf{N a}^{+}$ & $\mathbf{K}^{+}$ & Ca & Mg & HCO & $\mathrm{CO}_{3}$ & $\mathrm{Cl}^{-}$ & $\mathrm{SO}_{4}$ & $\mathrm{Fe}$ & $\mathrm{Ni}$ & $\mathbf{P b}$ & Zn \\
\hline \multirow{5}{*}{ Am1 } & Min & 1.9 & 0.3 & 0.0 & 0.4 & 0.4 & 0.01 & 2268.8 & 3.9 & 0.10 & 0.083 & 0.008 & 0.02 \\
\hline & $\operatorname{Max}$ & 10 & 12.3 & 22.0 & 25.0 & 50.0 & 0.1 & 5814 & 26.9 & 2.01 & 0.039 & 0.027 & 0.18 \\
\hline & Mean & 4.2 & 5.2 & 8.7 & 8.3 & 15.2 & 0.1 & 3732 & 13.4 & 0.45 & 0.022 & 0.024 & 0.08 \\
\hline & SD & 2.3 & 4.2 & 8.4 & 8.1 & 16.1 & 0.02 & 1493 & 7.6 & 0.69 & 0.012 & 0.003 & 0.07 \\
\hline & $\mathrm{CV}$ & 0.5 & 0.8 & 1.0 & 1.0 & 1.1 & 0.4 & 0.4 & 0.6 & 1.53 & 0.561 & 0.144 & 0.88 \\
\hline \multirow{5}{*}{ Am2 } & Min & 2.2 & 2.0 & 2.0 & 3.9 & 0.2 & 0.02 & 3013 & 6.0 & 0.09 & 0.002 & 0.002 & 0.05 \\
\hline & Max & 6.0 & 96 & 34.0 & 30.2 & 35 & 0.1 & 13825 & 47.5 & 0.28 & 0.086 & 0.096 & 0.14 \\
\hline & Mean & 3.8 & 12.5 & 18.0 & 11.1 & 15.3 & 0.1 & 9140 & 20.2 & 0.13 & 0.043 & 0.047 & 0.09 \\
\hline & SD & 0.9 & 23 & 8.5 & 7.9 & 15.5 & 0.02 & 4144 & 15.4 & 0.07 & 0.034 & 0.047 & 0.03 \\
\hline & $\mathrm{CV}$ & 0.2 & 1.8 & 0.5 & 0.7 & 1.01 & 0.3 & 0.5 & 0.76 & 0.52 & 0.794 & 1.010 & 0.36 \\
\hline \multirow{5}{*}{ VS1 } & Min & 1.5 & 2.3 & 0.0 & 0.1 & 0.20 & 0.01 & 1631 & 2.48 & 0.09 & 0.008 & 0.006 & 0.03 \\
\hline & Max & 23.5 & 15.8 & 26.0 & 24.1 & 40.0 & 0.1 & 11415 & 39.4 & 0.24 & 0.083 & 0.065 & 0.18 \\
\hline & Mean & 4.9 & 5.8 & 14.1 & 7.8 & 14.1 & 0.0 & 5106 & 9.84 & 0.14 & 0.045 & 0.036 & 0.09 \\
\hline & $\mathrm{SD}$ & 5.0 & 4.1 & 8.9 & 7.0 & 14.4 & 0.0 & 3252 & 12.3 & 0.05 & 0.028 & 0.025 & 0.05 \\
\hline & $\mathrm{CV}$ & 1.0 & 0.7 & 0.6 & 0.9 & 1.02 & 0.8 & 0.6 & 1.25 & 0.37 & 0.612 & 0.700 & 0.60 \\
\hline \multirow{4}{*}{ VS2 } & Min & 3.3 & 0.5 & 0 & 0.4 & 0.20 & 0.01 & 2552 & 3.51 & 0.09 & 0.005 & 0.041 & 0.02 \\
\hline & Max & 37.5 & 22 & 24.0 & 35.4 & 40 & 0.1 & 12620 & 22.7 & 116.3 & 0.105 & 0.118 & 0.30 \\
\hline & Mean & 12.2 & 8.2 & 12.6 & 10.8 & 12.7 & 0.1 & 6681 & 14.3 & 11.93 & 0.040 & 0.087 & 0.10 \\
\hline & SD & 10.5 & 5.3 & 8.5 & 8.4 & 13.3 & 0.0 & 3465 & 5.78 & 35.71 & 0.035 & 0.036 & 0.08 \\
\hline & $\mathrm{CV}$ & 0.9 & 0.6 & 0.7 & 0.8 & 1.05 & 0.5 & 0.5 & 0.40 & 2.99 & 0.888 & 0.418 & 0.80 \\
\hline
\end{tabular}
(Am2) and having an average of 7.01. This result is similar to those reported by Ogunkoya and Adejuwon (1990) and Jaji et al. (2007) in studies conducted in parts of southwest Nigeria.

Table 1. Summary statistics of physicochemical and heavy metals in groundwater of inland valleys in the study area. 


\begin{tabular}{|c|c|c|c|c|c|c|c|c|c|c|c|c|c|}
\hline IV & Statistic & $\mathbf{N a}^{+}$ & $\mathbf{K}^{+}$ & $\mathbf{C a}$ & Mg & HCO & $\mathrm{CO}_{3}$ & $\mathrm{Cl}^{-}$ & $\mathrm{SO}_{4}$ & $\mathbf{F e}$ & $\mathbf{N i}$ & $\mathbf{P b}$ & Zn \\
\hline \multirow{5}{*}{ LD1 } & Min & 1.8 & 0.3 & 0.0 & 0.3 & 0.20 & 0.01 & 3439 & 8.51 & 0.08 & 0.005 & 0.018 & 0.01 \\
\hline & $\operatorname{Max}$ & 39.5 & 97.3 & 14.0 & 20.6 & 40 & 0.1 & 16165 & 511.7 & 0.34 & 0.131 & 0.110 & 0.13 \\
\hline & Mean & 9.3 & 15 & 5.8 & 4.9 & 26.9 & 0.04 & 8973 & 66.1 & 0.12 & 0.064 & 0.064 & 0.05 \\
\hline & SD & 12.1 & 23.3 & 4.9 & 5.5 & 14.9 & 0.04 & 4819 & 147.3 & 0.10 & 0.053 & 0.039 & 0.04 \\
\hline & $\mathrm{CV}$ & 1.3 & 1.5 & 0.8 & 1.1 & 0.55 & 0.9 & 0.5 & 2.23 & 0.83 & 0.827 & 0.611 & 0.82 \\
\hline \multirow{5}{*}{ LD2 } & Min & 2.4 & 0.5 & 0 & 0.2 & 0.20 & 0.01 & 778 & 5.32 & 0.08 & 0.001 & 0.001 & 0.01 \\
\hline & $\operatorname{Max}$ & 38.5 & 28 & 22 & 26.5 & 255 & 0.1 & 13117 & 98.9 & 55.04 & 0.061 & 0.113 & 0.12 \\
\hline & Mean & 16.7 & 8.3 & 9.6 & 5.7 & 30.1 & 0.03 & 6902 & 25.3 & 7.43 & 0.024 & 0.060 & 0.07 \\
\hline & SD & 12.4 & 7.3 & 8.6 & 6.7 & 55 & 0.03 & 3412 & 25.1 & 18.61 & 0.026 & 0.048 & 0.03 \\
\hline & $\mathrm{CV}$ & 0.7 & 0.9 & 0.9 & 1.2 & 1.8 & 0.8 & 0.5 & 1.0 & 2.50 & 1.084 & 0.798 & 0.48 \\
\hline
\end{tabular}

All the values are in $\mathrm{mg} / \mathrm{L}$. Min = minimum; Max = maximum; $S D=$ standard deviation; $I \mathrm{~V}=$ inland valley; Am $=$ Amphitheatre - head inland valley; VS = Valley-side inland valley; LD = Low-slope depression inland valley.

The cationic content of the waters is generally low (Table 1) with an average dominance structure of the order $\mathrm{Na}^{+}>\mathrm{Ca}^{2+}>\mathrm{K}^{+}>\mathrm{Mg}^{2+}$. The dominance structure across the sites is of the order $\mathrm{Ca}^{2+}>\mathrm{Mg}^{2+}>$ $\mathrm{K}^{+}>\mathrm{Na}^{+}$for Am1, Am2, and VS1 valleys, and $\mathrm{Ca}^{2+}$ $>\mathrm{Na}^{+}>\mathrm{Mg}^{2+}>\mathrm{K}^{+} ; \mathrm{K}^{+}>\mathrm{Na}^{+}>\mathrm{Ca}^{2+}>\mathrm{Mg}^{2+}$; and $\mathrm{Na}^{+}$ $>\mathrm{Ca}^{2+}>\mathrm{K}^{+}>\mathrm{Mg}^{2+}$ for $\mathrm{VS} 2$, LD1, and LD2, respectively. The overall dominance pattern for anions is of the order $\mathrm{Cl}^{-}>\mathrm{SO}_{4}{ }^{2-}>\mathrm{HCO}_{3}{ }^{-}>\mathrm{CO}_{3}$. For the individual inland valleys, the anionic dominance structure is of the order $\mathrm{Cl}^{-}>\mathrm{HCO}_{3}>\mathrm{SO}_{4}>\mathrm{CO}_{3}$ in $\mathrm{Am} 1, \mathrm{VS} 1$, and $\mathrm{LD} 2$, and $\mathrm{Cl}^{-}>\mathrm{SO}_{4}>\mathrm{HCO}_{3}>\mathrm{CO}_{3}$ in Am2, VS2, and LD1. The cationic and anionic concentrations in water samples indicate that they are generally suitable for irrigated agriculture. The values obtained are also comparable with those reported by earlier studies in the region (e.g. Ige et al. (2008), Nwankwoala and Nwagbogwu (2012), and Olorunfemi et al. (2011)). For example, Nwankwoala and Nwagbogwu (2012) reported that in groundwater samples around Akure and environment of southwest Nigeria, $\mathrm{Ca}^{2+}, \mathrm{Mg}^{2+}, \mathrm{Na}^{+}$, and $\mathrm{HCO}_{3}$ ranged between 12.3 and 92.2, 0.9 and 32.6, 1.07 and 8.7, and 28 and $88 \mathrm{mg} / \mathrm{L}$, respectively.

The groundwater mean concentrations of $\mathrm{Fe}$ were $0.45,0.13,0.14,11.93,0.12$, and $7.43 \mathrm{mg} / \mathrm{L}$ in Am1, Am2, VS1, VS2, LD1, and LD2, respectively, with outlier values of $116.3 \mathrm{mg} / \mathrm{L}$ in VS2 and 55.04 in LD2. According to Ayers and Westcot (1994), iron concentrations > $5.0 \mathrm{mg} / \mathrm{L}$ may cause nutritional imbalances in some crops. The $\mathrm{Ni}$ content was generally low, with the mean concentration of 0.022 , $0.043,0.045,0.040,0.064$, and $0.061(\mathrm{mg} / \mathrm{L})$ at Am1, Am2, VS1, VS2, LD1, and LD2, respectively. These values were lower than the limit of $0.5 \mathrm{mg} / \mathrm{L}$ to
$1.0 \mathrm{mg} / \mathrm{L}$ suggested by (Ayers and Westcot, 1994). Concentrations greater than this level may be toxic to a number of plants. The concentration of lead $(\mathrm{Pb})$ in the waters was generally lower than the recommended value of $5.0 \mathrm{mg} / \mathrm{L}$ for plants. Very high concentrations in irrigation water can inhibit plant cell growth. For all the sites, the concentrations ranged from $0.001 \mathrm{mg} / \mathrm{L}$ to $0.118 \mathrm{mg} / \mathrm{L}$. $\mathrm{Zn}$ is an essential nutrient for most plants, though its high concentration is toxic. The values obtained from the inland valleys ranging between 0.01 and $0.18 \mathrm{mg} / \mathrm{L}$ were lower than the recommended maximum concentration of $2.0 \mathrm{mg} / \mathrm{L}$. At all the sites, the concentration of $\mathrm{Cu}$ was below the detection level of the equipment used. It can be concluded that the concentrations of heavy metals in the waters of the inland valleys of the study area were generally within the recommended limits.

\subsection{Characteristics of major water quality indices in groundwater of the study area}

Table 2 shows the groundwater quality indices of the inland valleys. The mean electrical conductivity $(\mathrm{dS} / \mathrm{m})$ values were $0.19,0.52,0.32$, $0.30,0.22$, and 0.21 in Am1, Am2, VS1, VS2, LD1, and LD2, respectively. The seasonal average values ranged from 0.24 to $0.3 \mathrm{dS} / \mathrm{m}$. An outlier value of 1.1 $\mathrm{dS} / \mathrm{m}$ was recorded at a location (P7) in Am2 during the dry season. The majority of the water samples fall within low saline to moderately saline water types as measured using the suitability rating scale provided by Richards et al. (1954). These water types are rated to be generally safe for the irrigation purpose.

Table 2. Summary statistics of major water quality indices in groundwater of the study area.

\begin{tabular}{||c|c|c|c|c|c|c|c|c|c||}
\hline \hline IV & Statistic & EC & SAR & \% Na & TDS & PI & MAR & KR & RSBC \\
\hline \multirow{4}{*}{ Am1 } & Min & 0.03 & 0.12 & 10.21 & 16 & 17.2 & 27.92 & 0.07 & -0.99 \\
\cline { 2 - 11 } & Max & 0.41 & 0.81 & 79.87 & 261.76 & 454.9 & 100 & 3.26 & 0.49 \\
\cline { 2 - 11 } & Mean & 0.19 & 0.36 & 35.08 & 123.63 & 143.9 & 73.70 & 0.60 & -0.13 \\
\cline { 2 - 11 } & SD & 0.11 & 0.22 & 22.78 & 69.81 & 135.5 & 26.56 & 0.79 & 0.47 \\
\cline { 2 - 11 } & CV & 0.56 & 0.6 & 0.65 & 0.56 & 0.9 & 0.36 & 1.33 & -3.63 \\
\hline \multirow{4}{*}{ Am2 } & Min & 0.18 & 0.12 & 8.72 & 113.92 & 11.2 & 31.44 & 0.06 & -1.69 \\
\cline { 2 - 10 } & Max & 3.06 & 13.02 & 49.56 & 1957.12 & 137.1 & 76.54 & 4.48 & 0.31 \\
\cline { 2 - 10 } & Mean & 0.52 & 0.99 & 19.74 & 329.60 & 44.9 & 50.08 & 0.39 & -0.70 \\
\cline { 2 - 10 } & SD & 0.72 & 3.21 & 10.66 & 457.95 & 33.4 & 13.75 & 1.09 & 0.60 \\
\cline { 2 - 10 } & CV & 1.39 & 3.23 & 0.54 & 1.3894 & 0.7 & 0.275 & 2.78 & -0.86 \\
& & & & & & & & & \\
\hline \hline
\end{tabular}




\begin{tabular}{|c|c|c|c|c|c|c|c|c|c||}
\hline \hline IV & Statistic & EC & SAR & \% Na & TDS & PI & MAR & KR & RSBC \\
\hline \multirow{4}{*}{ VS1 } & Min & 0.08 & 0.07 & 9.21 & 49.92 & 11.1 & 22.39 & 0.04 & -1.20 \\
\cline { 2 - 11 } & Max & 0.56 & 1.30 & 96.09 & 360.96 & 908.3 & 100 & 13.05 & 0.66 \\
\cline { 2 - 11 } & Mean & 0.32 & 0.57 & 34.87 & 202.67 & 128.5 & 50.22 & 1.41 & -0.46 \\
\cline { 2 - 11 } & SD & 0.14 & 0.32 & 21.81 & 89.23 & 220.7 & 23.94 & 2.88 & 0.59 \\
\cline { 2 - 11 } & CV & 0.44 & 0.55 & 0.625 & 0.4403 & 1.7 & 0.477 & 2.05 & -1.29 \\
\hline \multirow{4}{*}{ VS2 } & Min & 0.08 & 0.13 & 8.02 & 49.28 & 11.8 & 17.42 & 0.05 & -1.19 \\
\cline { 2 - 10 } & Max & 0.59 & 3.65 & 91.16 & 376.32 & 325.7 & 100 & 5.79 & 0.33 \\
\cline { 2 - 10 } & Mean & 0.30 & 0.82 & 37.98 & 192.37 & 77.7 & 60.35 & 0.94 & -0.42 \\
\cline { 2 - 10 } & SD & 0.13 & 0.86 & 22.72 & 81.75 & 72.1 & 21.52 & 1.63 & 0.54 \\
\cline { 2 - 10 } & CV & 0.42 & 1.04 & 0.598 & 0.4249 & 0.9 & 0.357 & 1.73 & -1.29 \\
\hline \multirow{4}{*}{ LD1 } & Min & 0.04 & 0.12 & 11.77 & 27.52 & 22.8 & 4.61 & 0.07 & -0.69 \\
\cline { 2 - 10 } & Max & 0.55 & 3.08 & 86.26 & 352.64 & 283.9 & 100 & 2.83 & 0.47 \\
\cline { 2 - 10 } & Mean & 0.22 & 0.77 & 55.73 & 142.16 & 120.0 & 60.43 & 0.81 & 0.04 \\
\cline { 2 - 10 } & SD & 0.14 & 0.81 & 21.01 & 91.76 & 78.3 & 27.35 & 0.73 & 0.34 \\
\hline \multirow{4}{*}{ LD2 } & 0.65 & 1.05 & 0.377 & 0.66 & 0.7 & 0.45 & 0.9 & 8.85 \\
\cline { 2 - 10 } & Min & 0.05 & 0.16 & 13.01 & 31.36 & 23.6 & 7.23 & 0.09 & -1.09 \\
\cline { 2 - 10 } & Max & 0.58 & 4.38 & 91.83 & 370.56 & 284.1 & 100 & 7.86 & 3.78 \\
\cline { 2 - 10 } & Mean & 0.21 & 1.56 & 56.96 & 134.91 & 112.8 & 52.03 & 2.19 & -0.06 \\
\cline { 2 - 9 } & SD & 0.12 & 1.14 & 24.81 & 74.36 & 82.9 & 32.44 & 2.17 & 1.02 \\
\hline \hline
\end{tabular}

Note: All the values are in meq/L except $\mathrm{pH}, \mathrm{TD}(\mathrm{mg} / \mathrm{L})$ and $\mathrm{EC}(\mathrm{dS} / \mathrm{m})$. Min $=$ minimum; Max $=$ maximum; $S D=$ standard deviation; $I V=$ inland valley; $A m=$ amphitheatre - head inland valley; $V S=$ Valley-side inland valley; $L D=l o w$ slope depression inland valley.

The electrical conductivity of the groundwater is comparable with those reported by Nwankwoala and Nwagbogwu (2012), who found that the concentration of EC in the groundwater of Akure environ in southwest Nigeria was in the range of 0.12 $-1.0 \mathrm{dS} / \mathrm{m}$, and the mean was $0.36 \mathrm{dS} / \mathrm{m}$. According to Wilcox (1955), conductivities of less than 0.2 $\mathrm{dS} / \mathrm{m}$ are permissible for irrigation. Average values of SAR (meq/L) of $0.35,1.05,0.35,0.80,0.78$, and 1.42 were obtained for Am1, Am2, VS1, VS2, LD1, and LD2 inland valley sites, respectively. The values were generally lower during the wet months than during the dry months. According to the classification based on Richards et al. (1954), $95.7 \%$ of the water samples were found within the range of excellent to good category.
Figures 4 and 5 show the plots of SAR (alkali hazard) and specific conductance (salinity hazard) following Richards et al. (1954) for water samples collected in the wet and dry seasons. The wet season plot indicates that all the samples fall within C1S1 (low salinity-low sodium) and C2S1 (medium salinity-low sodium) water type, except the sample (AIV2) in Am2 that had a higher value, which falls within very high salinity-low sodium (C3S3) class. The plot of the dry season samples (Figure 5) indicates that the majority of the samples are within the low sodium (S1) and low to medium salinity (C1-C2) category.

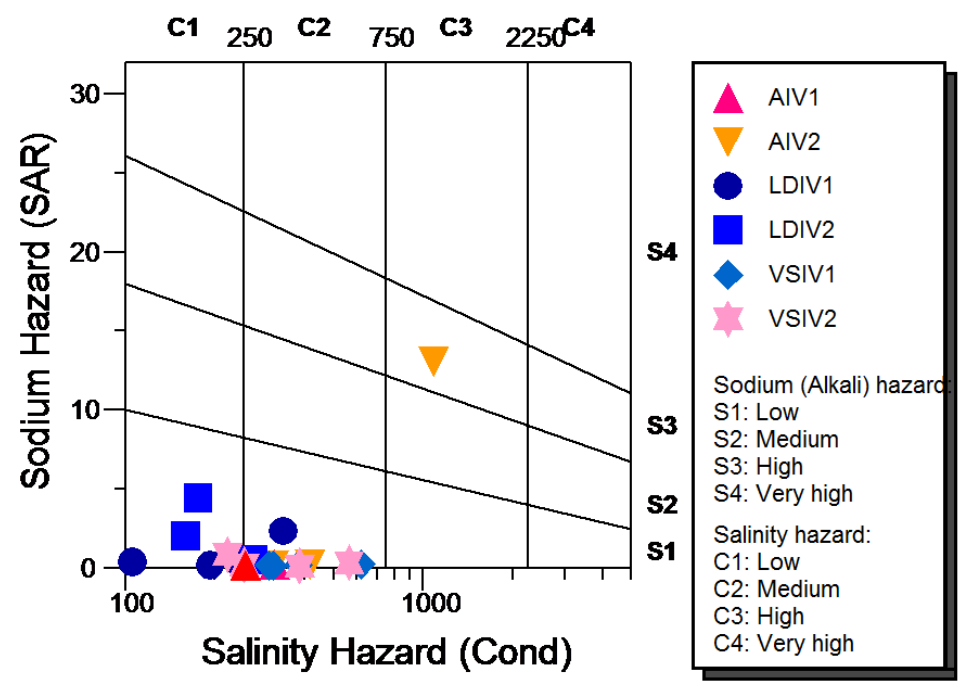

Figure 4. Classification of groundwater samples collected in the wet season with respect to salinity and sodium hazards. AIV1/AIV2, LDIV1/LDIV2, and VSIV1/VSIV2 are samples collected from amphitheatre - head inland valley (Am), valley-side inland valley (VS) and low-slope depression inland valley sites, respectively. 


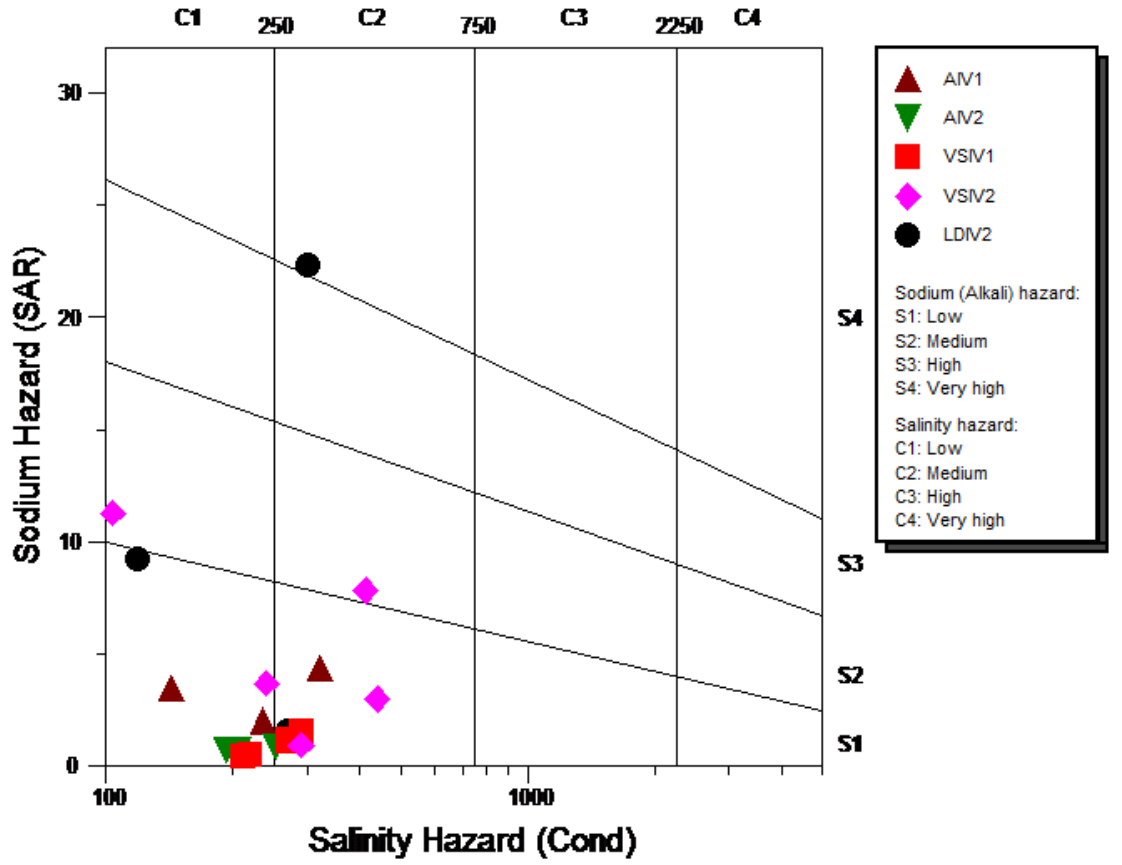

Figure 5. Classification of groundwater samples collected in the dry season with respect to salinity and sodium hazards. AIV1/AIV2, LDIV1/LDIV2, and VSIVI/VSIV2 are samples collected from amphitheatre - head inland valley (Am), valley-side inland valley (VS) and low-slope depression inland valley sites, respectively.

The soluble sodium percentage $(\% \mathrm{Na})$ of the groundwater ranged from 6.06 to $69.71 \%, 5.49$ to $73.91 \%, 3.28$ to $51.03 \%, 4.24$ to $83.68 \%, 5.78$ to $73.69 \%$ and 6.77 to $87.09 \%$ in Am1, Am2, VS1, VS2, LD1, and LD2, respectively. Based on the classification given by Wilcox (1955), 55.55\%, $93.75 \%, 85 \%, 79.84 \%, 18.30 \%$, and $30 \%$ of the groundwater samples fall within excellent and good with respect to usefulness for cropping in Am1, Am2, VS1, VS2, LD1, and LD2, respectively (Table 2).

The total dissolved solids (TDS) of the groundwater ranged from 16 to $261.76,113.92$ to $1957.12,49.92$ to $360.96,49.28$ to $376.32,27.52$ to
352.64 and 31.36 to $370.56 \mathrm{mg} / \mathrm{L}$ in sites Am1, Am2, VS1, VS2, LD1, and LD2, respectively. Higher values were recorded in the rainy season months than in the dry season months; and in the inland valleys located in the southern part of the study area (Am1, Am2, VS1, and VS2) than in those of the northern part (LD1 and LD2). According to the classification given by Robinove et al. (1958), the groundwater of the study area is mostly non-saline $(99.1 \%$ ) and is excellent for cropping (Table 3). This result is similar to those obtained by other research works around the study area.

Table 3. Classification of soluble sodium percentage (Na\%) and total dissolved solids (TDS) in groundwater (extended from Fipps (2003) and Richards et al. (1954)).

\begin{tabular}{|c|c|c|c|c|c|c|c|c|}
\hline \multirow{2}{*}{ Index } & \multirow{2}{*}{ Classification } & \multirow{2}{*}{ Range } & \multicolumn{6}{|c|}{ \% of Sample } \\
\hline & & & Am1 & Am2 & VS1 & VS2 & LD1 & LD2 \\
\hline \multirow{6}{*}{$\mathrm{EC}(\mathrm{dS} / \mathrm{m})$} & Low saline & Below 0.25 (Totally save) & 66.7 & 43.8 & 35.0 & 50 & 62.2 & 60.0 \\
\hline & Moderately saline & $\begin{array}{c}0.25 \text { - } 0.75 \text { (Save for all } \\
\text { conditions) }\end{array}$ & 33.3 & 43.8 & 65.0 & 50 & 37.5 & 40.0 \\
\hline & Medium to high salinity & $\begin{array}{c}0.75-2.25 \text { (Save only with } \\
\text { permeable soils and moderately } \\
\text { leaching) }\end{array}$ & 0 & 12.5 & 0 & 0 & 0 & 0 \\
\hline & High salinity & $2.25-4.0$ (Unsafe) & 0 & 0 & 0 & 0 & 0 & 0 \\
\hline & Very high salinity & $4.0-6.0$ (Unsafe) & & 0 & 0 & 0 & 0 & 0 \\
\hline & Excessive salinity & Above 6.0 (Unsafe) & 0 & 0 & 0 & 0 & 0 & 0 \\
\hline \multirow{4}{*}{$\begin{array}{l}\text { Total } \\
\text { Dissolved } \\
\text { Solids } \\
(\mathrm{mg} / \mathrm{L})\end{array}$} & Non saline & $<1000$ & 100 & 100 & 100 & 100 & 100 & 100 \\
\hline & Slightly Saline & $1000-3000$ & 0 & 0 & 0 & 0 & 0 & 0 \\
\hline & Moderately saline & $3000-10000$ & 0 & 0 & 0 & 0 & 0 & 0 \\
\hline & Very saline & $>10000$ & 0 & 0 & 0 & 0 & 0 & 0 \\
\hline \multirow{5}{*}{$\operatorname{SSP}(\%)$} & Excellent & $<20$ & 44.4 & 75 & 40 & 16.7 & 6.25 & 10 \\
\hline & Good & $20-40$ & 11.1 & 18.8 & 45 & 54.2 & 12.5 & 20 \\
\hline & Permissible & $40-60$ & 33.3 & 6.25 & 15 & 12.5 & 37.5 & 25 \\
\hline & Doubtful & $60-80$ & 11.1 & 0 & 10 & 4.17 & 31.25 & 30 \\
\hline & Unsuitable & $>80$ & 0 & 0 & 5 & 12.5 & 12.5 & 15 \\
\hline
\end{tabular}


The permeability index (PI) is an important factor which influences quality of irrigation water in relation to soil. It is affected by the amount of sodium, calcium, magnesium, and bicarbonate content of irrigation water (Nagaraju et al., 2006). Doneen (1964) developed a scheme for assessing the suitability of water for irrigation based on the permeability index. Waters classified as Class I and Class II are categorised as good for irrigation with $75 \%$ or more maximum permeability, while those classified as Class III are unsuitable with $25 \%$ of maximum permeability. For this study, sites Am1, Am2, VS1, VS2, LD1, and LD2 had 92.86\%, $66.67 \%, 82.25 \%, 95 \%, 93.75 \%$, and $90 \%$ of the groundwater samples falling within Class I and Class II PI index, suggesting that the groundwater of the study area is generally suitable for irrigation. This result is similar to those obtained by Talabi et al. (2014) in their studies in parts of southwest Nigeria; they found that the majority of the groundwater had PI Class II, with only a small percentage unsuitable for irrigation.

The mean values of Kelly's ratio (KR) obtained were $0.60,0.39,1.41,0.94,0.81$, and $2.19 \mathrm{meq} / \mathrm{L}$ for Am1, Am2, VS1, VS2, LD1, and LD2, respectively. The lowest values were recorded in September and the highest in January. Following Kelly's (1963) classification, $77.78 \%, 93.75 \%, 85 \%, 79.17 \%$, $68.75 \%$, and $45 \%$ of the groundwater samples in sites Am1, Am2, VS1, VS2, LD1, and LD2 had Kelley's ratio below $<1$. This suggests that the groundwater of the inland valleys is generally suitable for irrigation. The mean values of magnesium adsorption ratio (MAR) in the groundwater were $73.70,50.08$, 50.22, 60.35, 60.43, and 52.03 meq/L in Am1, Am2, VS1, VS2, LD1, and LD2, respectively. According to Raghunath (1987), MAR values > 50\% are considered harmful and unsuitable for irrigation purposes. Based on this, 22.22\%, 50\%, 65\%, 20.83\%, $31.25 \%$, and $60 \%$ of the groundwater samples in Am1, Am2, VS1, VS2, LD1, and LD2 inland valleys, respectively, fall above the acceptable limit. This suggests that the groundwater of some inland valleys may not be suitable for irrigation. This result is close to Odukoya et al. (2013) results, who found that 33\% of groundwater samples had MAR less than $50 \%$. However, the result differs from those of Talabi et al. (2014), who found that water samples were generally below the MAR value of $50 \%$.

Suitability of water for the irrigation purpose is also influenced by the amount of carbonate and bicarbonate in water. Irrigating with water with high residual sodium bicarbonate (RSBC) can result in soil infertility due to deposition of sodium carbonate. Concentration of RSBC in the groundwater of the site ranged from -0.99 to $0.49,-1.69$ to $0.31,-1.20$ to $0.66,-1.19$ to $0.33,-0.69$ to 0.47 , and -1.09 to 3.78 $\mathrm{meq} / \mathrm{L}$ in Am1, Am2, VS1, VS2, LD1, and LD2, respectively. The lowest values occurred in September and the highest in January. The negative values of RSBC obtained for some of the water samples indicate that in these waters $\mathrm{Na}^{+}$build-up is unlikely due to sufficient available $\mathrm{Ca}^{2+}$ and $\mathrm{Mg}^{2+}$ in excess of what can be precipitated as $\mathrm{CO}_{3}{ }^{2-}$ and $\mathrm{HCO}_{3}{ }^{-}$(Talabi et al., 2014). According to the classification given by Gupta and Gupta (1987), all the groundwater samples had RSBC below $<1.5$, suggesting that the groundwater of the inland valleys can be considered safe for cropping purposes.

A comparative evaluation of the hydrogeochemistry for equality of distributions of water quality parameters/indices between the valley types using Mann-Whitney $U$ tests (2-tailed) revealed that amphitheatre valley types Am1 and Am2 were not different significantly (Mann-Whitney $U=214$, $\mathrm{n} 1=\mathrm{n} 2=21, P<0.88)$. The same results of MannWhitney $U=180, \mathrm{n} 1=\mathrm{n} 2=21, P<0.31$ and MannWhitney $U=218, \mathrm{n} 1=\mathrm{n} 2=21, P<0.96$, were obtained for sites VS1 and VS2, and LD1 and LD2, respectively. Kruskal-Wallis H test (2-tailed) showed that there was no statistically significant difference in the distributions of hydro-geochemistry in all the sites, $P=0.935$, with the mean rank hydrochemistry score of 59.62 for site Am1, 60.43 for site VS1, 61.81 for site Am2, 63.57 for site LD1, 64.76 for site LD2, and 70.81for site VS2.

\section{Conclusions}

The study revealed that the cationic content of the groundwater of the inland valleys was generally low compared with the anionic content. The dominance structures of the major cations and anions were in the order of $\mathrm{Na}^{+}>\mathrm{Ca}^{2+}>\mathrm{K}^{+}>\mathrm{Mg}^{+}$and $\mathrm{Cl}^{-}$ $>\mathrm{SO}_{4}{ }^{2-}>\mathrm{HCO}_{3}{ }^{-}>\mathrm{CO}_{3}$, respectively. The $\mathrm{pH}$ indicates an acidic to alkaline water type. The concentration of heavy metals in the waters of the inland valleys of the study area were generally within the recommended limits and suitable for irrigated agriculture. The seasonal average values of EC ranged from 0.24 to $0.3 \mathrm{dS} / \mathrm{m}$. The majority of the water samples fall within low saline to moderately saline water types and are rated to be generally safe for irrigational purpose. The results are comparable with those reported in the literature for areas around the study area.

The results also showed that the values of major water quality indices, i.e. sodium adsorption ratio, soluble sodium percentage, total dissolved solids, permeability index, magnesium adsorption ratio, Kelly's ratio, and residual sodium bicarbonate in the groundwater of the study area were generally within the levels suitable for agricultural utilisation. The evaluation of hydro-geochemistry for equality of distributions of water quality parameters/indices between the valley types revealed that amphitheatre, valley-side and low depression valley types were not significantly different (Mann-Whitney $U=214, \mathrm{n} 1=$ $\mathrm{n} 2=21, P<0.88$; Mann-Whitney $U=180, \mathrm{n} 1=\mathrm{n} 2$ $=21, P<0.31$ and Mann-Whitney $U=218, \mathrm{n} 1=\mathrm{n} 2$ $=21, P<0.96$, respectfully). In addition, KruskalWallis $\mathrm{H}$ test (2-tailed) showed that there was no statistically significant difference in the distributions of hydro-geochemistry between the inland valley sites, $P=0.935$, with the mean rank hydrochemistry 
score of 59.62 for site Am1, 60.43 for site VS1, 61.81 for site Am2, 63.57 for site LD1, 64.76 for site LD2, and 70.81 for site VS2.

The study concluded that the groundwater of the inland valley agro-ecosystems of the study area was generally suitable for agricultural utilisation. The assessment of the dynamics of surface and the groundwater of the ecosystems as well as their morphological characterisation in relation to sustainable use for agriculture is recommended for further studies.

\section{References}

Aboyeji, O. S. \& Ogunkoya, O. O. (2014). Assessment of groundwater dynamics for agricultural use in six inland-valley agro-ecosystems of SW Nigeria. Tropical Agriculture (Trinidad), 91(2), 98-109.

Adebisi, A. A. (1981). The physico-chemical hydrology of a tropical seasonal river - Upper Ogun River. Hydrobiologia 79, 157-165. http://dx.doi.org/10.1007/ BF00006123.

Ayers, R. S. \& Westcot, D. W. (1994). Water quality for agriculture FAO irrigation and drainage. FAO Irrigation and Drainage Paper No 29(1). FAO. Retrieved from: http://www.fao.org/DOCReP/003/T0234e/T0234e00.ht m. (accessed 18/05/2015)

Doneen, L. D. (1964). Notes on water quality in agriculture. Dept. of Water, Science and Engineering, Univ. of California, Davis, USA.

Fagbami, A. \& Ajayi, F. O. (1990). Valley bottom soils of the sub-humid tropical southwestern Nigeria on basement complex: characteristics and classification. Soil Sci Plant Nutr, 26, 179-194. http://dx.doi.org/ $\underline{10.1080 / 00380768.1990 .10414983}$

Fipps, G. (2003). Irrigation Water Quality Standards and Salinity Management Strategies. Texas A\&M University. Retrieved from http://hdl.handle.net/ 1969.1/87829 (accessed 18/04/2015).

Gupta, S. K. \& Gupta, I. C. (1987). Management of Saline Soils and Water. Oxford and IBH Publication Coy, New Delhi, India.

Ige, O. O., Bale, R. B., \& Olasehinde, P. I. (2008). Physiochemical characteristics of water sources in Imeko, Southwestern, Nigeria. Water Res, 18, 32-36.

Jaji. M., Bamgbose. O. O., Odukoya, O. O., \& Arowolo, T. A. (2007). Water quality assessment of Ogun river, South West Nigeria. Environ Monit Assess, 133, 473482. http://dx.doi.org/10.1007/s10661-006-9602-1.

Kelly, W. P. (1963). Use of Saline Irrigation Water. Soil Sci, 95(4). http://dx.doi.org/10.1097/00010694196306000-00003.

Mukherjee, S., Kumar, B. A., \& Körtvélyessy, L. (2005). Assessment of groundwater quality in the South 24Parganas, West Bengal Coast, India. Journal of Environmental Hydrology, 13(Paper 15).

Nagaraju, A., Suresh, S., Killham, K., \& Hudson-Edwards, K. (2006). Hydrogeochemistry of Waters of Mangampeta Barite Mining Area, Cuddapah Basin, Andhra Pradesh, India. Turkish Journal of Engineering and Environment Sciences, 30, 203-219.

Nwankwoala, H. O. \& Nwagbogwu, C. N. (2012). Characteristics and quality assessment of groundwater in parts of Akure, South-Western Nigeria. Journal of Environmental Science and Water Resources, 1(4), 6773.
Odukoya, A. M., Folorunso, A. F., Ayolabi, E. A., \& Adeniran, E. A. (2013). Groundwater Quality and Identification of Hydrogeochemical Processes within University of Lagos, Nigeria. Journal of Water Resource and Protection, 5, 930-940. http://dx.doi.org/ 10.4236/jwarp.2013.510096.

Ogban, P. I. \& Babalola, O. (2003). Soil characteristics and constraints to crop production in inland valley bottoms in south-western Nigeria. Agricultural Water Management, 61, 13-28. http://dx.doi.org/10.1016/ S0378-3774(02)00170-1.

Ogban, P. I. \& Babalola, O. (2009). Characteristics, Classification and Management of Inland Valley Bottom Soils for Crop Production in sub-humid southwestern Nigeria. Journal of Tropical Agriculture, Food, Environment and Extension, 8(1), 1-13.

Ogunfowokan, A. O., Obisanya, J. F., \& Ogunkoya, O. O. (2009). Assessment of chemical quality of three streams under different agricultural land systems in Obafemi Awolowo University Ile-Ife, Nigeria. Toxicological \& Environmental Chemistry 91(5), 847872. http://dx.doi.org/10.1080/02772240802615066.

Ogunkoya, O. O. \& Adejuwon, J. O. (1990). Water chemistry of some rivers draining the basement complex in southwestern Nigeria. Hydrobiol Trop, 23(1), 3-10.

Ogunremi, L. T., Okusami, T. A., Olaniyan, G. O., Nwankwor, G. I., \& Ogunsola, O. A. (2000). The reconnaissance characterization of Nigerian inland valleys. A publication of Inland Valley Consortium Nigerian Coordinating Unit (IVC - NCU).

Olorunfemi, A. O., Salahudeen, K. S., \& Adesiyan, T. A. (2011). Ground water quality in Ejigbo town and environs, south-western Nigeria. Ife Journal of Science, 13(1), 111-120.

Page, A. L., Miller, R. H., \& Kenny, D. R. (1982). Methods of Soil Analysis. No. 9. Part 2: Chemical and Microbilogical Properties. Am. Soc. Agron., Madison, WI, USA.

Prasanth, S. V. S., Magesh, N. S., Jitheshlal, K. V., Chandrasekar, N., \& Gangadhar, K. (2014). Evaluation of groundwater quality and its suitability for drinking and agricultural use in the coastal stretch of Alappuzha District, Kerala, India. Applied Water Science 2, 165175. http://dx.doi.org/10.1007/s13201-012-0042-5.

Raghunath, I. M. (1987). Groundwater. 2 ed. Wiley Eastern Ltd., New Delhi, India.

Richards, L. A. et al. (eds) (1954). Diagnosis and Improvement of Saline and Alkali Soils. USDA Agricultural Handbook No. 60. US Department of Agriculture, Washington DC. 160 p. http://dx.doi.org/ 10.1097/00010694-195408000-00012.

Robinove, C. J., Longfort, R. H., \& Brook, J. W. (1958). Saline water resource of North Dakota vol Geological Survey Water-Supply Paper 1428. United States Government Printing Office, Washington.

Talabi, A. O., Afolagboye, O. L., Tijani, M. N., Aladejana, J. A., \& Ogundana, A. K. (2014). Hydrogeochemistry of Some Selected Springs' Waters in Ekiti Basement Complex Area, Southwestern Nigeria. International Journal of Engineering And Science, 3(2), 19-30.

Talabi, A. O. \& Tijani, M. N. (2013). Hydrochemical and stable isotopic characterization of shallow groundwater system in the crystalline basement terrain of Ekiti area, southwestern Nigeria. Applied Water Science 3, 229245. http://dx.doi.org/10.1007/s13201-013-0076-3.

Thenkabail, P.S. \& Nolte, C. (1996). Capabilities of Landsat-5 Thematic Mapper (TM) data in regional mapping and characterization of inland valley agroecosystems in West Africa. International Journal 
of Remote Sensing 17(8), 1505-1538. http://dx.doi.org/ 10.1080/01431169608948721.

Todd, D. K. \& Mays, L. W. (2005). Groundwater Hydrology $3^{\text {rd }}$ Edition. Wiley and Sons Inc., New York, U.S.

Wallender, W. W. \& Tanji, K. K. (eds) (2012). ASCE Manual and Reports on Engineering Practice No. 71 Agricultural Salinity Assessment and Management $\left(2^{\text {nd }}\right.$ Edition). American Society of Civil Engineers, Reston, VA.

West African Rice Development Association (WARDA). (1996). Annual Report 1996. West African Rice Development Association, Bouaké.

Wilcox, L. V. (1955). Classification and Use of Irrigation Waters. Department of Agriculture, United States. Washington D.C.

Windmeijer, P. N. \& Andriesse W. (Eds.) (1993). Inland Valleys in West Africa: An Agro-ecological Characterization of Rice-Growing Environments. ILRI Publication 52. International Institute for Land Reclamation and Improvement, Wageningen, The Netherlands. 


\title{
Drèkinimui skirto gruntinio vandens kokybès įvertinimas pasirinktose toli nuo jūros esančio pietvakarių Nigerijos slẻnio žemès ūkio ekosistemose
}

\author{
Olatunji S. Aboyeji ir Olayinka O. Ogunkoya \\ ${ }^{I}$ Regioninis aviaciniu kosminiu topografiniu matavimu mokymu centras (RECTAS), Ile-Ife, Osuno valstija, \\ Nigerija. \\ ${ }^{2}$ Geografijos departamentas, Obafemi Awolowo universitetas, Ile-Ife, Osuno valstija, Nigerija.
}

(gauta 2015 m. kovo mèn.; priimta spaudai 2015 m. birželio mėn.)

Tyrime buvo ịvertinta gruntinio vandens kokybė šešiose toli nuo jūros esančiose (IV) žemès ūkio ekosistemose, siekiant nustatyti jo tinkamumą laukų apsodinimui pietvakarių Nigerijos savanoje. Vandens bandiniai buvo matuojami pjezometrais lietinguoju ir sausuoju sezonais, buvo analizuotos jų fiziocheminès savybės ir sunkiųų metalų kiekiai. Vandens panaudojimo drèkinimo tikslams tinkamumui nustatyti buvo naudojami pagrindiniai vandens kokybès rodikliai ir jie buvo palyginti su priimtais standartais. Tyrimas parodè, kad vandens bandiniai ịprastai buvo neutralūs arba lengvai šarminiai, o dominuojanti katijonų ir anijonų struktūra buvo tokios sekos $\mathrm{Na}^{+}>\mathrm{Ca}^{2+}$ $>\mathrm{K}^{+}>\mathrm{Mg}^{2+}$ ir $\mathrm{Cl}^{-}>\mathrm{SO}_{4}{ }^{2-}>\mathrm{HCO}_{3}{ }^{-}>\mathrm{CO}_{3}$. Sunkiųų metalų koncentracijos reikšmès įprastai buvo tarp rekomenduojamų ribų daugumai pasėlių rūšių, auginamų tiriamojoje teritorijoje. Pagrindiniai vandens kokybès rodikliai (natrio adsorbcijos santykis, tirpaus natrio procentas, bendras ištirpusių dalelių rodiklis, dirvožemio pralaidumo rodiklis, magnio adsorbcijos santykis, Kelly's santykis ir likutinio natrio bikarbonato kiekis) ịprastai buvo tarp pasėliams tinkamų ribų. Kruskal-Wallis $\mathrm{H}$ testas (dvikryptis) parodė, kad jokio statistiškai žymaus vandens kokybès parametrų (rodiklių) skirtumo tarp toli nuo jūros esančių slènių vietų nebuvo, kai $P=0.935$. Nustatyta, kad gruntinis toli nuo jūros esančių slènių žemès ūkio ekosistemų vanduo tiriamojoje teritorijoje buvo tinkamas žemès ūkio naudojimui.

Raktiniai žodžiai: pietvakariụ Nigerija, gruntinis vanduo, pelké, žemès ūkis, vandens kokybės rodikliai. 